\title{
Experiêneia religiosa: da Reforma Protestante ao avivamento pentecostal
}

Recebido: 24/06/2016. Aprovado: 20/07/2016.

\author{
Paulo Jonas dos Santos Júnior* \\ André Luís da Rosa**
}

Resumo: Para uma análise precisa da atual sociedade como um produto humano historicamente construído, é necessário considerar a Reforma Protestante como um dos seus principais marcos. A experiência religiosa é o que dá origem a qualquer fenômeno religioso, que posteriormente é organizado em ritos e doutrinas. Nessa perspectiva, é mister observar que os principais acontecimentos oriundos da Reforma são frutos de uma nova perspectiva da relação entre o fiel e o sagrado. Esta é caracterizada, principalmente, pela relação individual entre o fiel e o sagrado, livre das mediações da Igreja Católica Romana. No século $X X$, surgiu no meio protestante o Movimento Pentecostal, que transformou o cenário cristão mundial com sua nova vivência do sagrado, denominada batismo no Espírito Santo.

Palavras-chave: Experiência religiosa. Protestantismo. Pentecostalismo.

Abstract: For a precise analysis of the present society as a human product historically constructed, it's necessary to envisage the Protestant Reformation as one of its principal landmarks. Religious experience gives origin to any religious phenomenon, which is afterwards organized in rites and doctrines. In this perspective, it's necessary to observe that the main results from the Reformation are fruits from a new perspective of the relation between the faithful and the sacred. This is characterized mainly by an individual relation, free from the mediations of the Roman Catholic Church. In the XX century, aroused in the protestant milieu the Pentecostal Movement, which transformed the world Christian scenery with its new experience of the sacred, called the baptism in the holy Spirit.

Keywords: Religious experience. Protestantism. Pentecostalism.

* Mestre em Ciências das Religiões, Faculdade Unida de Vitória, ES. Especialista em História e Cultura do Brasil, UNESA, Rio de Janeiro, RJ. Licenciado em História, ISEED, Virginópolis, MG. Bacharel em Teologia, FAECAD, Rio de Janeiro, RJ. Psicanalista Clinico, FATEB, Rio de Janeiro, RJ. Membro da Convenção Geral das Assembleias de Deus no Brasil (CGADB).

** Mestrando em Ciências das Religiões, Faculdade Unida de Vitória, ES. Bacharel em Filosofia, Faculdade São Luiz, Brusque, SC. Membro da Rede Latino-Americana de Estudos do Pentecostalismo - Núcleo Brasil (RELEP). 


\section{Introdução}

Para uma análise precisa da atual sociedade como um produto humano historicamente construído, é necessário considerar a Reforma Protestante como um dos principais marcos de tal história. ${ }^{1}$ A Reforma não afetou apenas o ambiente litúrgico do Cristianismo, ela ultrapassou as paredes do templo e serviu de apoio para diversos fatos que ocorreram e ainda continuam a ocorrer na sociedade, como o surgimento de novas denominações cristãs e o rompimento, em diversos países, da política com o clero romano. Nessa perspectiva, é mister observar que os principais acontecimentos oriundos da Reforma são frutos de uma nova perspectiva da relação entre o fiel e o sagrado defendida pelos protestantes.

A experiência religiosa é o que dá origem a qualquer fenômeno religioso; e a organização de ritos e liturgias, a elaboração de conceitos teológicos e morais são precedidas por uma experiência do sagrado. Se considerar o cristianismo ocidental, o rompimento dos protestantes com o catolicismo romano delineou uma nova forma de os cristãos se relacionarem com Deus. A partir do século XX, outra novidade no mundo cristão surgiu: o pentecostalismo. Este, por sua vez, trouxe uma nova compreensão de vivência religiosa. Apresentar as principais características da experiência religiosa no protestantismo histórico e no pentecostalismo, eis o objetivo deste artigo.

\section{Protestantismo histórico: a religião da Palavra}

A Reforma Protestante é daqueles acontecimentos que assinalam o fim de uma época e o começo de outra. Essa função coube à Reforma (embora não somente a ela) no que diz respeito ao desenvolvimento daquele novo modo de conceber a realidade e daquele singular tipo de cultura que chamamos moderno. Por isso, alguns historiadores, não sem razão, colocam o início da época moderna não na descoberta da América (1492), mas na afixação das 95 teses nas portas da Igreja de Wittenberg (1517). A reforma protestante foi um acontecimento essencialmente religioso, mas causou ao mesmo tempo profundas transformações políticas, sociais, econômicas e culturais. Também no desenvolvimento da filosofia a sua influência foi decisiva, especialmente na filosofia alemã, bem como, na francesa, inglesa, americana e italiana; em poucas palavras,

1 Cf. ALMEIDA, J. Thomaz. Calvino e sua Herança. 2. ed. Vitória: Gráfica Lisboa, 2012. p. 7. 
em toda a filosofia moderna. Isso justifica e exige um estudo bastante amplo e aprofundado sobre as causas, os autores e os ideais da Reforma Protestante. $^{2}$

A base teológica da Reforma é apoiada nas 95 teses que Martinho Lutero publicou na porta da igreja do Castelo de Wittenberg em 31 de Outubro de 1517, em que protestou contra vários pontos da Igreja, propondo uma reforma.Tais teses foram abraçadas por governantes e líderes religiosos de diversos países da Europa, como Alemanha, Suíça, França e Reino Unido; o que resultou no rompimento da unidade da igreja cristã ocidental originando os denominados cristãos católicos, seguidores de Roma e do papa, e os cristãos protestantes, seguidores das teses de Lutero.

A Europa do final do século XV e princípio do século XVI era profundamente influenciada pela força da Igreja Católica Romana. Os tentáculos da Igreja atravessavam as paredes do templo e dominavam os governantes e os principais escalões da sociedade. O poder Papal era absoluto e inquestionável e em troca desse poderoso apoio reis e governantes dispensavam grande auxílio financeiro à Igreja Católica. ${ }^{3}$

O sopro de renovação trazido pelas ordens religiosas dos franciscanos e dos dominicanos nos séculos precedentes não tinha sido suficiente para reformar os organismos centrais da hierarquia da Igreja: cúria romana, cardeais, e bispos eram corruptos, e os próprios papas agiam muitas vezes apenas como soberanos terrenos envolvidos nas lutas políticas, esquecidos de sua missão fundamental, como sucessores de Pedro, de guias espirituais da cristandade. ${ }^{4}$

Dessa forma, diversos teólogos já haviam protestado contra os abusos de poder exercidos por parte da Igreja Católica. Tais pensadores ficaram conhecidos como pré-reformadores, e desses podemos destacar a figura do inglês John Wycliffe, considerado por muitos como sendo o precursor da Reforma Protestante.

Ele, no século XIV, contestou diversos princípios do cristianismo vivido pela Igreja Católica. Suas ideias eram movidas pela crença de que a Igreja deveria adotar o princípio da pobreza, assim como se dedicar à

2 Cf. MONDIN, Battista. Curso de filosofia. São Paulo: Paulus, 2006. p. 30.

3 Cf. ALMEIDA, 2012, p. 36.

4 MONDIN, 2006, p. 30-31. 
pregação do evangelho e à vida espiritual dos seus fiéis. Para Wycliffe, a Igreja não deveria se ocupar das questões políticas . Tal assunto deveria ser deixado para os reis e governantes, aos quais incumbia a missão de cuidar da vida social da população.

No século XV, na Boêmia, John Huss, inspirado pelos escritos de Wycliffe, inicia um movimento que torna legítimo o sacerdócio universal dos crentes e ao mesmo tempo defende a tese de que todos podem estabelecer uma comunicação com Deus independentemente da figura dos sacramentos ou da Igreja Romana. Sua posição de pregador sinodal facilitou a rápida propagação de suas teorias; tal postura fez com que angariasse admiradores e ao mesmo tempo conquistasse a oposição da Igreja Católica, o que resultou em sua condenação à morte.

Esses acontecimentos influenciaram fortemente aquela geração, que mesmo com a forte oposição por parte da Igreja Católica Romana continuou a persistir. Cento e dois anos após Huss, Martinho Lutero publica suas teorias que vão culminar na Reforma Protestante. Das noventa e cinco teses publicadas por Martinho Lutero, as principais são: $5^{\circ}: o$ papa não pode perdoar nenhuma pena além das que são impostas pela sua vontade ou pelos cânones; $52^{\circ}$ : é vão confiar na salvação por causa das cartas de indulgências; $67^{\circ}$ :as indulgências, tão exaltadas pelos pregadores, têm apenas um mérito, o de conseguir dinheiro. ${ }^{5}$

\subsection{O produto religioso da Reforma Protestante}

As bases fundamentais reformistas podem ser resumidas nos cinco pontos principais das teses desenvolvidas sobre as reflexões de Lutero a partir da exegese bíblica. Tais pontos fundamentais ficaram conhecidos como os cinco sola, que são: Sola Scriptura, Solus Christus, Sola Gratia, Sola Fides, Soli Deo Gloria. ${ }^{6}$ Do latim, sola significa "somente", e os cinco sola tinham como objetivo combater as doutrinas em uso pela Igreja Católica Apostólica Romana.

Fazendo uma análise das bases defendidas pelos reformadores, é possível verificar que os argumentos da doutrina Protestante visavam combater, entre outras causas, o papel de intermediadora assumida pela Igreja Romana, e essa nova visão sobre a forma de se relacionar com o

5 Cf. Ibid., p. 33.

6 Cf. BOYER, Orlando. Os Heróis da Fé. Rio de Janeiro: CPAD, 2002. p. 45. 
sagrado foi de suma importância para a expansão e aceitação da Reforma Protestante. ${ }^{7}$

Sola Scriptura refere-se ao reconhecimento de que a Bíblia sagrada é a única regra de fé inspirada capaz de guiar o fiel à vontade de Deus. Dessa forma, a doutrina reformada afirma que as bulas papais ou as tradições da Igreja Católica não têm nenhuma autoridade para guiar os fiéis a uma prática cristã genuína ${ }^{8}$. Esse pilar da Reforma foi de extrema importância na relação entre o fiel e o sagrado, uma vez que, segundo ele, nenhum ser humano tem autoridade de falar em nome de Deus, ou seja, o papa e o mais simples camponês ocupam o mesmo patamar no escalão divino. Um dos principais textos usados para defender esse visão é II Timóteo 3, 16-17:

toda a Escritura é inspirada por Deus e útil para o ensino, para a repreensão, para a correção, para a educação na justiça, a fim de que o homem de Deus seja perfeito e perfeitamente habilitado para toda boa obra. ${ }^{9}$

Sobre a experiência com a Bíblia, Martinho Lutero escreve:

Então, achei-me recém-nascido e no paraíso, toda as Escrituras tinham para mim outro aspecto, perscrutava-as para ver tudo quanto ensinam sobre a justiça de Deus. ${ }^{10}$

Outro pilar defendido pelos reformadores é o Solus Christus. Este ponto da doutrina reformada afirma que a salvação do homem é realizada exclusivamente por Cristo. Dessa perspectiva é negada toda forma de alcançar a redenção proposta pela Igreja Romana através dos decretos papais. Ou seja, dessa maneira, os santos e beatos da Igreja Católica perdem totalmente seus significados. Assim sendo, o Solus Christus trouxe aos que abraçaram a causa reformada uma certeza de que não mais era necessário a figura eclesial da Igreja Romana, bastaria apenas aceitar o sacrifício de Cristo na cruz do Calvário. Um dos textos básicos utilizados pelos reformadores é o de Atos dos Apóstolos 4.12:

\footnotetext{
Cf. ALVES, Rubem. Religião e Repressão. São Paulo: Loyola, 2012. p. 172.

8 Cf. ALMEIDA, 2012, p. 99.

$9 \quad$ BíBLIA Sagrada, King James; 2. ed. São Paulo: Bv Books, 2010.

10 LUTERO, Martinho. Catecismo Maior. São Leopoldo: Sinodal, 2007. p. 12.
} 
e não há salvação em nenhum outro: porque abaixo do céu não existe nenhum outro nome, dentre os homens, pelo qual importa que sejamos salvos. ${ }^{11}$

O Sola Gratia ${ }^{12}$ afirmava que a causa da salvação da humanidade não é outra a não ser a Graça de Deus. Da perspectiva desse pilar, os reformadores afirmaram que ninguém se salva por mérito próprio, por obras, indulgências, sacrifícios, penitências, ou por deliberação da Igreja Católica. Declara, porém, que o veículo causador da salvação é exclusivamente a graça de Deus. Ao receber essas palavras, os fiéis se sentiam libertos das imposições da Igreja Romana, ou seja, ninguém precisaria seguir as resoluções do papa para obter a salvação, porque ela está disponivel por graça divina. Como argumento sobre a eficácia da graça, o texto de Efésios 2. 8-9 é muito utilizado pelos protestantes: "Porque pela graça sois salvos, mediante a fé; e isso não vem de vós; é dom de Deus; não de obras, para que ninguém se glorie". ${ }^{13}$

Outro importante pilar da doutrina dos reformadores que modificou o modo do fiel se relacionar com o divino foi o Sola Fide. Após meditar no texto bíblico e se deparar com a frase: o justo viverá da fé, Lutero entende que a graça de Deus é manifestada no homem simplesmente pela fé, não sendo necessária nenhuma intervenção humana nesse processo. Ou seja, o fiel deve buscar a fé para alcançar o favor divino, desqualificando assim as indulgências e penitências como formas legítimas de se alcançar as benesses de Deus. O texto de Romanos 1:17 foi um dos textos mais usados por Lutero durante sua vida, onde está escrito: "mas o Justo viverá pela fé".

Ao proclamar Soli Deo Gloria o protestantismo se opõe claramente ao ensino da Igreja Católica Apostólica Romana de que o homem deve devoção aos santos canonizados pelo papa. Tal ensinamento reformado abre a possibilidade ao fiel de prestar culto somente a Deus, pois segundo esse ensino, cultuar ou venerar qualquer homem, vivo ou morto, ou outro ser que não seja o Deus Pai de Jesus e Criador do Universo, é um ato reprovável. João 4.24 diz: ${ }^{14}$ "Deus é espírito, e é necessário que os seus adoradores o adorem em espírito e em verdade".

11 BíBLIA Sagrada, King James; 2. ed. São Paulo: Bv Books. 2010.

12 Cf. ALMEIDA, 2009, p. 135.

13 BÍBLIA Sagrada, King James; 2. ed. São Paulo: Bv Books. 2010.

14 BíBLIA Sagrada, King James; 2. ed. São Paulo: Bv Books. 2010. 
Dessa perspectiva, é mister observar que o princípio religioso reformado tem o foco diferente do que defende o católico romano. Enquanto este defende que somente através da Igreja se é capaz de alcançar o verdadeiro cristianismo, aquele defende que a experiência cristã é alcançada através de uma busca individual por meio da pessoa de Cristo.

Assim, é importante perceber que o cristão adepto da doutrina protestante não comunga com a ideia de autoridade papal, sucessão apostólica ou mesmo de uma Igreja como porta-voz da vontade divina. Ao contrário, o cristão reformado defende o princípio do sacerdócio universal, e o livre acesso a Deus através da fé em Cristo Jesus. ${ }^{15}$

\subsection{Culto e experiência religiosa no protestantismo histórico}

Os princípios da reforma foram bem assimilados pela população de países como a Alemanha, Suíça, França, Reino Unido e outros. Os principais nomes da reforma, sem dúvida são o de Calvino e o de Lutero; a partir desses reformadores podemos fazer uma análise dos cultos oriundos da Reforma Protestante e da experiência com o sagrado que obtêm os fiéis oriundos desse movimento. ${ }^{16}$

O culto luterano adota a Bíblia como norteadora da experiência espiritual. Dessa forma, a ligação com Deus é individual e deve ser buscada por cada crente. $O$ culto luterano também tem uma atmosfera de gratidão e é pautado no perdão misericordioso recebido pela graça de Deus.

O culto calvinista é bastante objetivo. Para Calvino, a Bíblia é a declaração da vontade de Deus e tem toda a autoridade. A atmosfera característica é a de reverente temor perante a vontade do Todo Poderoso. O sermão no culto calvinista é uma exposição da vontade de Deus declarada em todas as partes dos escritos sagrados. Sua liturgia é congregacional ${ }^{17}$.

15 Cf. ALMEIDA, 2009, p. 130.

16 Cf. ALVES, 2012, p. 115.

17 Culto onde há participação direta da congregação. Diferente da ritualística tradicional onde somente o sacerdote, e alguns assistentes, realizam funções, no culto congregacional pode haver participação de conjuntos, grupos e os fiéis podem trazer palavras ou entoar louvores. 
A Igreja Presbiteriana é um exemplo de igreja que guarda os princípios da Reforma Protestante. Sua teologia é baseada no reformador Calvino. O culto presbiteriano é baseado na centralidade do Deus Triuno, na mensagem expositiva centrada na vontade de Deus, e na reverência que deve ser pautada na adoção dos valores explícitos nas Escrituras. A teologia presbiteriana adota o princípio Calvinista da eleição divina. ${ }^{18}$

Com a propagação dos princípios protestantes, diversos movimentos ganharam forças, o que culminou no surgimento de diversas igrejas locais e nacionais. Essas igrejas nem sempre seguiam fielmente o princípio luterano ou calvinista. ${ }^{19}$ Com o tempo, batistas, anglicanos, puritanos, metodistas, adventistas e outras denominações começaram a surgir, trazendo ao cenário cristão suas visões sobre a doutrina bíblica. Porém, uma das principais transformações se deu quanto à visão de vida consagrada e a necessidade da oração. Ao adotar a oração como necessidade máxima da Igreja, o cenário da liturgia cristã tem uma mudança significativa. As reuniões em busca das virtudes do Espírito Santo para a Igreja passam a ser constantes, levando assim a Igreja a experimentar um novo tempo.

\section{Pentecostalismo: a religião da experiência}

Depois do protestantismo histórico surgiu o pentecostalismo, que transformou a experiência religiosa cristã. No início do século XX, não havia uma só igreja pentecostal, e hoje a maioria do povo evangélico é pentecostal. ${ }^{20} \mathrm{~A}$ primeira fase do pentecostalismo recebeu o nome de pentecostalismo clássico e nasceu nos círculos protestantes, mas não foi reconhecido pelas igrejas protestantes tradicionais, de modo que os adeptos fundaram logo igrejas próprias. Também, a partir do ano de 1956, surgiu o movimento pentecostal renovado, ou movimento carismático, no seio das igrejas protestantes tradicionais, como luteranos, anglicanos, presbiterianos, metodistas, batistas e outros grupos. ${ }^{21} \mathrm{E}$ o mais surpreendente é que a experiência pentecostal foi acolhida até mesmo pela Igreja Católica Romana, desde 1967.

18 Cf. Ibid., p. 117.

19 Cf. ALMEIDA,2009, p. 80.

20 MC ALISTER, Robert. A experiência pentecostal. São Paulo: Nova vida, [s. d.]. p. 7.

21 Cf. SMET, Walter. Eu faço um mundo novo: movimento carismático na Igreja. Tradução: Frans Van de Water. São Paulo: Loyola, 1978. p. 23. 
Falar de experiência religiosa no pentecostalismo é falar da especificidade deste movimento. Pois, para os pentecostais, conhecer a Deus é o mesmo que fazer a experiência pessoal de Deus. Portanto, a experiência religiosa no pentecostalismo pode ser entendida como:

[...] uma modalidade (e também fonte) de conhecimento imediato, enquanto não acontece pela atividade discursiva da inteligência, como seria a conclusão de um silogismo, nem por uma reflexão posterior, nem pelo acolhimento do saber em razão da autoridade ou de uma tradição histórica. Portanto, trata-se de uma percepção simples e imediata de algo, que provoca grande certeza fundada numa evidência específica. Naturalmente esta percepção possui sua dimensão intelectual, [...] mas ela, por si, implica todo o ser humano (inteligência, vontade, sentimentos, imaginação). ${ }^{22}$

Para Rudolf Otto, o sagrado apresenta-se como uma categoria complexa, que se constitui de dois elementos importantes: o elemento não-racional, definido por ele como numinoso, ${ }^{23} \mathrm{e}$ o elemento racional, que é o predicador. Sua obra, $O$ sagrado, apresenta como subtítulo: um estudo do elemento não-racional na ideia do divino e a sua relação com o racional. O termo não-racional, não é empregado por Otto com o sentido de oposição ao racional, como ele mesmo afirma: “[...] por não-racional não entendemos o que é sem forma e estúpido, o que não está ainda submisso ao controle da razão, o que é rebelde à racionalização em nossa vida instintiva ou nos mecanismos do mundo". ${ }^{24}$ E ele define o racional como o que pode captado pelo pensamento conceitual. Estas noções claras são condições para o ensinamento da fé. A doutrina, a catequese e os próprios livros sagrados utilizam-se de predicados racionais. ${ }^{25}$

22 MIRANDA, Mario de França. A experiência cristã e suas expressões históricas. In: ANJOS, Márcio Fabri dos (Org.). Experiência religiosa: risco ou aventura. São Paulo: Paulinas, 1998. p. 90. [Grifo do autor].

23 "Para denominar o caráter particular e puramente religioso do sagrado, Otto cunha a palavra numinoso. Numinoso vem da palavra latina numen e serve para indicar a característica essencial e exclusiva da religião, livre das conotação éticas e racionais contidas no termo sagrado". [BRICK, Bruno Odélio. O Sagrado em Rudolf Otto. Porto Alegre: EDIPUCRS, 1993, p. 24.] [Grifo do autor] E, nas palavras de Otto, "[...] compreende um elemento de qualidade absolutamente especial que se subtrai a tudo aquilo que nós chamamos de racional;é completamente inacessível à compreensão conceitual, e constitui algo inefável". [OTTO, Rudolf. O sagrado: um estudo do elemento não-racional na idéia do divino e a sua relação com o racional. Tradução: Prócoro Velasques Filho. São Bernardo do Campo: Metodista, 1985. p. 11.] [Grifo do autor]. OTTO, 1985, p. 61-62. 
Baseando-se na concepção de sagrado de Rudolf Otto, pode-se afirmar que o pentecostalismo resgata em sua vivência de fé o elemento não-racional da fé cristã, a experiência pessoal de Deus, ofuscada por liturgias ritualistas e doutrinas dogmáticas rígidas. O teólogo católico Yves Congar destaca que, nos movimentos de linha pentecostal, a referência à experiência tem primazia sobre qualquer outra. Pois, "o pentecostalismo introduz na vida ordinária das igrejas o exercício de zonas do homem negligenciadas por uma religião excessivamente organizada e racional". ${ }^{26}$ Basta perceber que o discurso pentecostal para atrair seus fiéis não está baseado em pregações doutrinárias, elaborações teológicas, mas na narrativa da experiência pessoal de Deus, o que Ele faz em minha vida. Como sintetiza o teólogo Elias Wolff:

há a fé experiencial, já que no pentecostalismo, mais que uma doutrina, um preceito, uma norma, o que importa é a experiência. O que convence quem assume ser pentecostal é o testemunho do vivido, que impregna de significado a existência e determina a compreensão da realidade sócio-religiosa. ${ }^{27}$

No pentecostalismo clássico a experiência do batismo com o Espírito Santo acompanhado do falar em línguas é normativa, é o que o define um pentecostal, é o que o capacita para o ministério. Por isso, todas as pessoas são motivadas a buscar sua própria experiência, como analisa Esdras Costa Bentho: "os relatos da experiência de batismo no Espírito Santo são variados, pessoais e não repetitivos, disso resulta a subjetividade da experiência". ${ }^{28} \mathrm{E}$ continua: "não há como transferir, reproduzir ou transmitir a mesma experiência a outros. Cada um deve ter sua própria experiência de batismo no Espírito Santo". ${ }^{29}$

Convém destacar, para não criar-se uma visão reducionista do pentecostalismo, que a experiência não substitui a racionalidade. Novamente citando Otto, para ele a religião não pode ser compreendida sem a interação dos seus aspectos racionais e não-racionais. Mas, ainda que haja esta interação necessária entre o racional e o não racional na

26 CONGAR, Yves. Ele é o Senhor e dá vida. São Paulo: Paulinas, 2005. p. 207.

27 WOLFF, Elias. Editorial. Caminhos de Diálogo: Revista de Diálogo Ecumênico e InterReligioso. Brasília: CNBB, n. 4, a. 3, p. 7-9, 2015. p. 8.

28 BENTHO, Esdras Costa. Entre a emoção e a razão: a experiência pneumatológica dos pentecostais clássicos. Caminhos de Diálogo: Revista de Diálogo Ecumênico e Inter-Religioso. Brasília: CNBB, n. 4, a. 3, p. 91-102, 2015. p. 98-99.

29 BENTHO, 2015, p. 99. 
religião, um desses aspectos deve preceder o outro e, para Otto, o não racional claramente precede o racional. A experiência precede a elaboração de conceitos. Segundo Otto, a religião necessita de firmes e sólidos conceitos, mas, o que ele faz, é apenas a constatação de que, para a religião, a construção de seu edifício teológico racional não é possível sem os alicerces da experiência religiosa. ${ }^{30}$ Assim, o que o pentecostalismo faz é valorizar a experiência espiritual, a dimensão interior da fé, e não dispensa a racionalidade da fé, ainda que em muitos casos esta se reduza ao fundamentalismo bíblico, como critério para o discernimento.

Ainda um fato que não pode ser ignorado: o pentecostalismo extrojetou-se para fora dos círculos protestantes e adentrou também o catolicismo romano, através da Renovação Carismática Católica. De fato, em toda a história do cristianismo, este é o primeiro movimento de origem protestante que adentrou a Igreja Católica Romana e foi aprovado por suas autoridades eclesiásticas. ${ }^{31} \mathrm{E}$ é do conhecimento de poucos católicos e pentecostais o fato de que, segundo o historiador pentecostal Vinson Synan, "a Renovação Carismática Católica (RCC) é, sem dúvida, uma das vertentes mais importantes do movimento carismático do século XX. É também o que apresentou um dos crescimentos mais surpreendentes" ${ }^{32}$ Assim, também no pentecostalismo católico a fé está baseada na experiência, pois a principal causa do processo de expansão da RCC nos setores populares "é a oferta de uma experiência religiosa subjetiva e emocional dentro das fronteiras do catolicismo". ${ }^{33}$

\subsection{Experiência pentecostal: características e intenções originárias}

Tendo estabelecido que a experiência do sagrado possua centralidade no pentecostalismo, podem-se apresentar algumas de suas principais características. Primeiramente, a experiência pentecostal é denominada batismo com o Espírito Santo, que pretende ser uma atualização da

30 Cf. SOUZA, Humberto Araujo Quaglio de. A experiência religiosa em Kierkegaard sob a perspectiva do pensamento de Rudolf Otto. 2013. 111 p. Dissertação [Mestrado em Ciência da Religião], Universidade Federal de Juiz de Fora, Juiz de Fora, 2013. p. 35.

31 Cf. SYNAN, Vinson. O século do Espírito Santo: 100 anos do avivamento pentecostal e carismático. Tradução: Judson Canto. São Paulo: Vida, 2009. p. 289.

32 SYNAN, 2009, p. 293.

33 MARTINS, Andrea Damacena. Pentecostalismo católico: desenvolvimento e direções no contexto brasileiro.Caminhos de Diálogo: Revista de Diálogo Ecumênico e InterReligioso. Brasília: CNBB, n. 4, a. 3, p. 33-42, 2015. p. 38. 
experiência vivenciada pelos Apóstolos no dia de Pentecostes. Mc Alister assim a define:

o batismo no Espirito Santo é uma experiência. Ele é uma sequência do arrependimento e faz parte do processo de regeneração. Sua evidência inicial é o falar em outras línguas. O batismo no Espírito Santo é um dom de Deus e a promessa do Pai. Ele dá ao crente um relacionamento intimo com Cristo e o revestimento de poder para testemunhar Cristo. O crente batizado no Espírito Santo está cheio do Espírito Santo e capacitado para exercer os demais dons espirituais. ${ }^{34}$

Para os pentecostais das Assembleias de Deus, por exemplo, o batismo em águas é uma ordenança de Jesus, enquanto que o batismo com o Espírito Santo é uma experiência considerada como 'segunda bênção', ocorrida logo após a pessoa ter recebido a bênção da salvação. ${ }^{35}$ Porém, o propósito do batismo com o Espírito Santo não é o falar em línguas, como sintetiza Adriano Lima e Diandra Brandt, baseando-se no teólogo pentecostal Antony Palma que diz: ele é um revestimento para testemunhar Cristo, é condição para exercer o ministério; capacita o crente para realizar milagres, bem como abre para a pessoa as portas para as manifestações espirituais e por fim contribui para que o cristão busque uma vida correta, santa. ${ }^{36}$

A intenção originária desta experiência de fé não era a de fundar novas igrejas, mas difundir o batismo com o Espírito Santo por todo o Cristianismo. Por isso o pentecostalismo surgiu com um grande fervor missionário e espalhou-se rapidamente por todo o mundo. Todos aqueles que recebessem o batismo no Espírito Santo, homens e mulheres, brancos ou negros, estavam capacitados para pregar a palavra de Deus, fato este que tornou o pentecostalismo nascente um movimento leigo e inclusivo, uma vez que todos eram capacitados pelo Espírito Santo.

Suas reuniões de oração ficaram conhecidas pelo fervor, pela pregação simples e existencial/testemunhal, pela musicalidade, pelas manifestações espirituais, pelo clima de irmandade, pela alegria. Uma

34 MC ALISTER, [s. d.], p.75-76.

35 Cf. LIMA, Adriano; BRANDT, Diandra. A experiência do batismo com o Espírito Santo e seus propósitos pastorais no pentecostalismo.Caminhos de Diálogo: Revista de Diálogo Ecumênico e Inter-Religioso. Brasília: CNBB, n. 4, a. 3, p. 43-53, 2015. p. 46. 
coisa é certa: o culto pentecostal vai ao encontro dos profundos anseios populares, como afirma Brakemeier:

el estilo pentecostal es acogido, de preferencia, entre las clases no privilegiadas de América Latina; mediante la promesa de la curación divina, la celebración de fiesta nel templo de Dios, la construcción de la autoestima, además de otros elementos. ${ }^{37}$

\subsection{Experiência pentecostal: alguns desdobramentos históricos}

O pentecostalismo nasceu com o propósito originário de ser uma corrente de espiritualidade, centrada mais na pessoa que na instituição, livre e inclusiva. No desenrolar de sua história, porém, percebe-se como que uma traição de sua vocação. De renovador a tradicional; de livre a institucional; de inclusivo a intolerante; de missionário a centralizado em suas estruturas; de leigo a sacerdotal; da lógica de irmandade à lógica de poder.

Apontam-se aqui apenas alguns exemplos de atitudes que o pentecostalismo adotou em sua história, que adulteram sua experiência religiosa originária. Se ele surgiu para dar voz a todos, uma vez que todos são capacitados pelo Espírito Santo, caracterizando-se assim como uma religião leiga, hoje se presencia a privatização da experiência do Espírito, com alguns líderes que se consideram detentores plenos dos dons do Espírito. Gedeon Alencar assim se expressa:

alguns líderes pentecostais estão a cada dia mais pomposos, imperiais e inacessíveis. Infaliveis em suas pregações, revelações e decretos. Sabem tudo e decidem tudo inquestionavelmente por revelação que lhes é dada diretamente pelo divino. Pastor é um título comum que não lhes serve mais, dai surgiram os pastores-doutores, profetas, apóstolos ou patriarca ou pai-apóstolo. ${ }^{38}$

Assim, quando um líder fala, é o próprio Deus quem fala. O leigo, pobre e simples, sem formação e títulos, não possui mais o direito de expressar-se, não pode mais ser canal da revelação de Deus.

37 BRAKEMEIER, Gottfried. Preservando la unidad Del Espíritu en el vínculo de la paz: un curso de ecumenismo. São Leopoldo: Sinodal; Quito: CLAI, 2008. p. 77.

38 ALENCAR, Gedeon Freire. Pentecostalismos e ecumenismos: Deus e o diabo se (des)entendendo na terra do sol. Caminhos. Goiânia: PUC, vol. 12, n. 1, p. 220-239, jan./jul. 2014. p. 233. 
Outra questão que se assinala é a de que o pentecostalismo surgiu como um movimento inclusivo, com a capacidade de aproximação das classes de pessoas mais sofridas e oprimidas, distantes dos ideais de uma sociedade capitalista. Eles anunciavam a salvação em Cristo, sem criar acepção entre as pessoas. ${ }^{39}$ Principalmente por sua pregação, que optou pela via inclusiva: "os pregadores pentecostais empregavam em seus discursos as linguagens populares, fato este que levou as massas a optarem por este movimento. [...] respondiam às demandas de necessidades das pessoas que viviam à margem da sociedade" ${ }^{40}$ Todavia, com o surgimento de líderes austeros, rígidos e inflexíveis, que passaram a valorizar o exterior através do moralismo e do legalismo dos usos e costumes, afastou-se o Movimento Pentecostal da sociedade. Segundo Ailto Martins, o pentecostalismo passou a ser um espaço para o cultivo da 'hipocrisia', pois "a austeridade exige perfeição dos fieis. Como ainda não existe ninguém perfeito [...], criou-se no Movimento Pentecostal a conduta hipócrita". ${ }^{41}$ A opressão devido às regras fez com que muitos deixassem estas igrejas e outros fossem expulsos. Devido a esta postura austera, segundo Martins, os pentecostais passaram a ser vistos como anticulturais, anti-intelectuais, erguendo-se barreiras entre crentes e incrédulos, puros e impuros, dificultando o relacionamento entre os pentecostais e a sociedade. ${ }^{42}$ Assim, a experiência do Espírito passa a ser reduzida apenas a um grupo de 'santos', que segue as normas estabelecidas por um grupo de líderes rígidos, afastando os 'impuros' desta experiência de fé.

Por fim, outra questão, que contradiz a experiência pentecostal originária, diz respeito ao denominacionalismo. De fato, o pentecostalismo não surgiu com a intenção de fundar novas igrejas, pois, segundo o pastor pentecostal Roger Cabezas:

o pentecostalismo é mais que uma doutrina (uma confissão), é uma maneira de viver e experimentar a fé cristã que emergiu do seio de diversas tradições confessionais. ${ }^{43}$

39 Cf. MARTINS, Ailton. Alteridade e austeridade no Movimento Pentecostal. Azusa: revista de estudos pentecostais. Joinville: Refidim, v. 2, n. 1, p. 29-46, 2012. p. 40-41.

40 MARTINS, Ailton. A linguagem inclusiva da teologia do pentecostalismo clássico: possibilidade de inclusão e acessibilidade de pessoas excluídas da sociedade. Azusa: revista de estudos pentecostais. Joinville: Refidim, v. 6, n. 2, p. 49-60, 2015. p. 50-51.

41 MARTINS, 2012, p. 33.

42 Cf. MARTINS, 2012, p. 34-35.

43 CABEZAS, Roger. Os dons do Espírito Santo: edificando o corpo. In. CASCO, Miguel Angel; CABEZAS, Roger; MANRÍQUEZ, Samuel Palma. Pentecostais, libertação e ecumenismo. São Leopoldo: CEBI, 1996, p. 32. 
Todavia, com o surgimento das igrejas pentecostais, muitas passaram a declararem-se detentoras plenas da verdade, combatendo outras igrejas. Ao invés do ardor missionário de espalhar a mensagem pentecostal, presencia-se uma disputa entre denominações: segundo Ismael de Vasconcelos, é "um pentecostalismo que ainda mantém tradições comuns, mas que vive uma concorrência consigo mesmo, através do denominacionalismo". ${ }^{44}$ Pois as divisões entre as denominações não acontecem, na maioria das vezes, por questões teológicas, mas político-institucionais. Assim, as igrejas mantêm as mesmas características pentecostais, porém, não possuem nenhuma unidade ou diálogo: ao contrário, estabelecem uma competição a fim de conquistar mais fiéis para si. ${ }^{45}$ Com isso, as igrejas pentecostais centram-se cada vez mais em suas instituições, num modelo eclesiológico autorreferencial, tornando-se aquilo que tanto criticaram nas igrejas tradicionais. Um exemplo pode ser as Assembleias de Deus, como comenta Gedeon Freire de Alencar em entrevista:

nunca as ADs foram tão tradicionais e 'católicas' como agora. Agora temos bispos, catedral, uma 'tradição assembleiana' a zelar, um corpo de doutrinadores (um Magistério). E muita riqueza física e simbólica a defender.[...] suas lutas internas, seus grupos de poder, seus próprios interesses internos, fazem delas cada vez mais autocentradas. ${ }^{46}$

Se o pentecostalismo surgiu com o sentimento de superação de um cristianismo institucional e burocrático, hoje ele vivencia a luta entre instituição e carisma no interior das próprias denominações. A lógica do poder institucional sacrifica a experiência religiosa em troca do crescimento das estruturas das igrejas, da comodidade dos líderes poderosos que se estabelecem dentro das denominações. Por isso, faz-se necessário uma leitura crítica de como as denominações têm organizado sua experiência religiosa pentecostal. Talvez as instituições pentecostais estejam mais institucionais do que imaginam.

44 FERREIRA, Ismael de Vasconcelos. "Para que todos sejam um": o conflito denominacionalista pentecostal e a questão do ecumenismo. In: OLIVEIRA, David Mesquiati de. Pentecostalismos e unidade. São Paulo: Fonte Editorial, 2015, p. 211. Cf. FERREIRA, 2015, p. 213.

46 Entrevista concedida via e-mail a André Luís da Rosa, sobre 'a Igreja Católica e as Assembleias de Deus', em 02/01/2016. 


\section{Conclusão}

Com a conquista de uma vivência religiosa fundada na relação individual entre o sujeito e o sagrado, sem instituições mediadoras, surgiram diversas igrejas oriundas da Reforma Protestante, com diversos modos de relacionarem-se com Deus, o que deu um novo rosto ao cristianismo. Com o pentecostalismo, por sua vez, houve uma nova afirmação da experiência subjetiva do sagrado, surgindo milhares de igrejas com novos costumes e liturgias. A experiência religiosa do pentecostalismo é responsável pela maior parte daquilo que cientistas da religião têm chamado de retorno ao sagrado, e tal prática influenciou todo o cristianismo.

Assim, cumprindo o objetivo deste artigo de apresentar as principais características da experiência religiosa no protestantismo histórico e no pentecostalismo, pode-se, ainda, constatar que no pentecostalismo parece não haver limites para a diversidade de formas de experiência religiosa. Um exemplo é o surgimento do neopentecostalismo, que possui em sua vivência religiosa e seus cultos elementos do pentecostalismo clássico e do protestantismo histórico. Porém, este é um fenômeno muito mais próximo do catolicismo popular brasileiro que das igrejas protestantes históricas, além de recorrer a elementos da Umbanda e do Espiritismo. Isso mostra que o campo evangélico brasileiro está em constante mutação.

\section{Referências}

ALENCAR, Gedeon Freire. Pentecostalismos e ecumenismos: Deus e o diabo se (des)entendendo na terra do sol. Caminhos. Goiânia: PUC, vol. 12, n. 1, p. 220-239, jan./jul. 2014.

ALMEIDA, J. Thomaz. Calvino e sua Herança. 2. ed. Vitória: Gráfica Lisboa, 2012.

ALVES, Rubem. Religião e Repressão. São Paulo: Loyola, 2012.

BENTHO, Esdras Costa. Entre a emoção e a razão: a experiência pneumatológica dos pentecostais clássicos. Caminhos de Diálogo: Revista de Diálogo Ecumênico e Inter-Religioso. Brasília: CNBB, n. 4, a. 3, p. 91-102, 2015.

BÍBLIA Sagrada, King James; 2. ed. São Paulo: Bv Books, 2010.

BOYER, Orlando. Os Heróis da Fé. Rio de Janeiro: CPAD, 2002. 
BRAKEMEIER, Gottfried. Preservando la unidad del Espíritu nel vínculo de la paz: un curso de ecumenismo. São Leopoldo: Sinodal; Quito: CLAI, 2008.

BRICK, Bruno Odélio. O Sagrado em Rudolf Otto. Porto Alegre: EDIPUCRS, 1993.

CABEZAS, Roger. Os dons do Espírito Santo: edificando o corpo. In. CASCO, Miguel Angel; CABEZAS, Roger; MANRÍQUEZ, Samuel Palma. Pentecostais, libertação e ecumenismo. São Leopoldo: CEBI, 1996. p. 18-38.

CONGAR, Yves. Ele é o Senhor e dá vida. São Paulo: Paulinas, 2005.

FERREIRA, Ismael de Vasconcelos. "Para que todos sejam um": o conflito denominacionalista pentecostal e a questão do ecumenismo. In: OLIVEIRA, David Mesquiati de. Pentecostalismos e unidade. São Paulo: Fonte Editorial, 2015. p. 209-217.

LUTERO, Martinho. Catecismo Maior. São Leopoldo: Sinodal, 2010.

MARTINS, Ailton. A linguagem inclusiva da teologia do pentecostalismo clássico: possibilidade de inclusão e acessibilidade de pessoas excluídas da sociedade. Azusa: revista de estudos pentecostais. Joinville: Refidim, v. 6, n. 2, p. 49-60, 2015.

Alteridade e austeridade no Movimento Pentecostal. Azusa: revista de estudos pentecostais. Joinville: Refidim, v. 2, n. 1, p. 29-46, 2012 .

MARTINS, Andrea Damacena. Pentecostalismo católico: desenvolvimento e direções no contexto brasileiro. Caminhos de Diálogo: Revista de Diálogo Ecumênico e Inter-Religioso. Brasília: CNBB, n. 4, a. 3, p. 33-42, 2015.

MC ALISTER, Robert. A experiência pentecostal. São Paulo: Nova vida, [s. d.].

MIRANDA, Mario de França. A experiência cristã e suas expressões históricas. In: ANJOS, Márcio Fabri dos (Org.). Experiência religiosa: risco ou aventura. São Paulo: Paulinas, 1998.

MONDIN, Battista. Curso de filosofia. São Paulo: Paulus, 2006. 
OTTO, Rudolf. O sagrado: Um estudo do elemento não-racional na ideia do divino e a sua relação com o racional. Tradução: Prócoro Velasques Filho. São Bernardo do Campo: Metodista, 1985.

SMET, Walter. Eu faço um mundo novo: movimento carismático na Igreja. Tradução: Frans Van de Water. São Paulo: Loyola, 1978.

SOUZA, Humberto Araujo Quaglio de. A experiência religiosa em Kierkegaard sob a perspectiva do pensamento de RudolfOtto. 2013. 111 p. Dissertação [Mestrado em Ciência da Religião], Universidade Federal de Juiz de Fora, Juiz de Fora, 2013.

SYNAN, Vinson. O século do Espírito Santo: 100 anos do avivamento pentecostal e carismático. Tradução: Judson Canto. São Paulo: Vida, 2009.

WOLFF, Elias. Editorial. Caminhos de Diálogo: Revista de Diálogo Ecumênico e Inter-Religioso. Brasília: CNBB, n. 4, a. 3, p. 7-9, 2015.

E-mail dos Autores: paulojsjunior@hotmail.com andreldarosa@hotmail.com 